\title{
Em nome do pai: ventriloquismo e subalternidade em Até que as pedras se tornem mais leves que a água, de António Lobo Antunes
}

\author{
Paulo Ricardo Kralik Angelini*
}

\begin{abstract}
Escrever é como matar um porco. É preciso ferir o coração do real, submetê-lo a nossa vontade, dizer a ele o que ele foi, e depois esquartejá-lo, expor suas vísceras.
\end{abstract}

Charles Kiefer

Às vezes o meu corpo gela, às vezes uma pedra levanta-se. Faltam muitas, ainda. Quando todas forem mais leves do que a água então sim, podem lerme, escrevi o que era preciso escrever.

Lobo Antunes

Morremos não a morte da guerra [...] mas a lenta, aflita, torturante agonia da espera.

Lobo Antunes

\section{Introdução}

A história recente de Portugal, construída e desconstruída pedra sobre pedra, apresenta enredos que praticamente já nasceram ficção, em que habitam supostos heróis e vilões, personagens em cenários exóticos, disputados, excluídos e partilhados. A atmosfera onírica contribui para uma quase ficcionalização da história, porque abundantemente recheada de absurdos que mesmo a ficção poderia negar. Mas se a guerra colonial aos nossos olhos de hoje parece uma incoerência difícil de encaixar, os mortos, feridos, mutilados, os filhos desta violência, gritam para bem longe dos manuais de história. Para além dos romances.

Doutor em Literaturas em Língua Portuguesa e professor da Pontifícia Universidade Católica do Rio Grande do Sul (PUC-RS), Porto Alegre, RS, Brasil. E-mail: paulo.angelini@pucrs.br 
É a matéria humana que parece sobreviver para o relato e a ficcionalização de um evento traumático. O humano fraturado, raiz arrancada, encharcado de sangue, que se faz remanescência e reminiscência. Sobras e memórias em campos destroçados, minas espalhadas num tabuleiro de xadrez, relógios que se negam ao movimento, solidão fardada.

A literatura tampouco é um campo neutro. Também ela apresenta suas armadilhas num território em que a explosão pode acontecer num trocar de linhas. Porque a literatura mergulha nos mundos possíveis, reais ou irreais, e reconstrói suas paredes e suas vísceras.

A guerra parece ser um tema bastante caro a António Lobo Antunes, totem gigantesco da literatura portuguesa. Suas primeiras obras traziam como espaço físico e especialmente psicológico - a África então colônia e os conflitos que justamente se assentavam numa esfera quase inventada. "Uma história inventada", dizia-nos o narrador de Os cus de fudas, um de seus textos inaugurais, lá no limite invisível entre os anos 1970 e 1980. "Começo a pensar que o milhão e quinhentos mil homens que passaram por África não existiram nunca" (ANTUNES, 2001, p. 79), porque "o gigantesco, inacreditável absurdo da guerra, me fazia sentir na atmosfera irreal, flutuante e insólita" (ANTUNEs, 2001, p. 61).

Quase quarenta anos depois - e com uma lista extensa de obras que também revisitam a guerra em Angola -, Lobo Antunes apresenta Até que as pedras se tornem mais leves que a água, lançado em outubro de 2017. Aqui, o mesmo tom onírico se faz presente, no embate entre dois sobreviventes de uma guerra, dois homens que se julgam fadados a morrer. $\mathrm{O}$ enevoado da narrativa recupera, predominantemente a partir de dois pontos de vista, mais do que o combate em Angola, o conflito de um soldado e seu filho trazido da África. Pai e filho compõem uma simbiose dissonante, porque carregada de vínculos opostamente construídos. Um homem branco que lutou a guerra colonial em Angola, que dizimou um povoado, mas poupou e arrancou daquela terra um menino preto, quatro ou cinco anos de idade. Traz o menino mesmo depois de matar sua mãe, cortar suas orelhas e suas mãos, mesmo depois de matar o seu pai, um homem deitado na terra. Outros combatentes não se furtam à recomendação: "Pense bem no que se mete olhe que mais tarde ou mais cedo vinga-se de si meu alferes" (ANTUnEs, 2017, p. 73).

A intrincada relação entre esses dois homens, manifestada numa construção narrativa não menos complexa - como aliás sempre é a obra antuniana -, é o ponto central do estudo que pretendo percorrer neste trabalho. Ao mesmo tempo, mergulho nessa espécie de revolta silenciosa ao patrimônio português por parte da personagem angolana, que reproduz o discurso do pai-branco-colonizador até que, por fim, decide literal e metaforicamente silenciá-lo. 


\title{
Da narração propositadamente pervertida: vozes num tempo-espaço embaralhado
}

\begin{abstract}
A vida-porco é também irrecuperável. A narração, com suas técnicas, com seus truques, esforça-se por imitar o porco, refazer fragmentos da vitalidade antiga, e só consegue produzir outro porco, outra vida.
\end{abstract}

Charles Kiefer

Até que as pedras se tornem mais leves que a água traz uma espécie de prólogo - única seção não numerada no total de 23 capítulos - narrado pela prima deste soldado, ou filha da prima, guardiã dos mortos de uma pequena aldeia portuguesa, também em extinção. É ela quem se dedica a fazer a memória sobreviver; é ela quem cuida dos jazigos dos mortos no cemitério; é ela quem anuncia, assim de supetão, todos os conflitos que o leitor encontrará na obra. Tem o homem que lutou na guerra um filho preto "que nunca foi seu filho embora o tratasse como filho e o preto o tratasse como pai" (ANTUNES, 2017, p. 11), ${ }^{1}$ filho trazido da guerra como pedaço de uma lembrança, "que quase todos os soldados voltavam com recordações, uma máscara, um boneco de pau, uma orelha numa garrafa de álcool, um garoto, um braço a menos" (p. 11). É ela quem toma conta dos jazigos dos mortos, já dissemos, e é ela quem cuida do jazigo do primo da sua mãe, o narrador da história que ainda nem começou, e já o sabemos morto. Neste mesmo cemitério repousa o outro narrador da obra, o filho preto - que a prima não chega a dizer que toma conta -, aquele que matou o pai "com a faca ainda cheia de sangue do animal, não outra faca, a mesma” (p. 12). Era no dia de matar porcos, tradição familiar seguida à risca pelo homem que lutou em Angola, ainda quando criança, quando seu vô e seu pai matavam o porco pendurado. O ritual segue sendo respeitado, nesta metáfora explícita do pequeno espetáculo cruel a que são submetidas as personagens centrais da obra: o homem que lutou na Guerra, sua esposa, sua filha, seu filho preto e a esposa deste. A lenta agonia do porco, que grunhe pelas páginas da obra, do início ao fim, equipara-se à lenta agonia desta morte anunciada do pai pelo filho, aqueles que ganham a tarefa de narrar a história de Até que as pedras se tornem mais leves que a água.

A concepção narrativa da obra enquadra-se naquilo que já podemos chamar de uma arquitetura antuniana, polifônica e transgressiva. São 23 capítulos, antecedidos por este prólogo, em que dois narradores principais, autodiegéticos, revezamse numa rememoração que apresenta tempos e espaços sobrepostos. Pai e filho tomam a voz e contam um passado-presente organicamente entrelaçado, mas também apontam para o futuro já anunciado pela prima: um deles matará; ambos morrerão. Se Genette vê em Robbe-Grillet uma referência temporal propositadamente pervertida, tomamos de empréstimo essa expressão para aplicá-la a Lobo Antu-

\footnotetext{
Para evitar a repetição e o excesso de informações, a partir de agora referenciarei o texto de Lobo Antunes com o qual trabalho apenas com o número da página.
} 
nes, uma vez que o autor português comete todo o tempo anacronias narrativas, ou melhor, "formas de discordância entre a ordem da história e a da narrativa" (GeNeTte, 2017, p. 94). As anacronias antunianas parecem ser uma marca desde suas primeiras obras, e mais do que um ir e voltar constante, trazem um embaralhamento proposital de vozes, tempos e espaços que exige especial atenção do leitor. Analepses e prolepses fundem-se a um tempo-agora tornando-se uma massa indivisível. O ontem-hoje revela-se impossível de desfazer-se, porque cada ato no passado verte-se num presente nunca delimitado neste aqui e num futuro tão previsível que já anunciado. A morte do pai e do filho é um falso spoiler; o que menos interessa é o que vai acontecer, porque toda a amarrada construção narrativa acaba por partir do depois para chegar neste antes.

Contudo, Genette não poderia dar conta das artimanhas narrativas exploradas por Antunes. Como bem sublinha Brian Richardson, na obra Unnatural voices: extreme narration in modern and contemporary fiction, há toda uma nova linhagem de textos ficcionais que transbordam as bacias metodicamente criadas por teóricos do século XX. Narrativas não-miméticas ou anti-miméticas desafiam não apenas os leitores, mas também os críticos de teoria da literatura. Diz Richardson (2006, p. 3): "It should be readily apparent that a model centered on storytelling situations in real life cannot begin to do justice to these narrators who become ever more extravagantly anti-realistic every decade".

No caso específico de Lobo Antunes, na obra estudada (mas também da mesma forma nas anteriores), os dois narradores autodiegéticos trazem outras consciências para dentro de seu próprio discurso. A começar por eles próprios: pai e filho adivinham-se os pensamentos, ao ponto de, em alguns capítulos, como, por exemplo, no 14, 16, 17 e 23; penetrarem na narração um do outro. Em geral, é o pai que invade o espaço do filho - o que é bastante simbólico. Isso ocorre na maioria dos capítulos iniciados pelo filho, em que surge o pai $(14,16,23)$. Por outro lado, o capítulo de número 17 também é significativo, pois a voz do pai aparece apenas no princípio; o filho rouba-lhe o protagonismo e apodera-se do capítulo praticamente do início ao fim.

Outras personagens igualmente interferem junto aos narradores principais. $\mathrm{O}$ filho parece ser mais poroso a essas outras vozes, atravessado que é pela mãe, pela irmã, pela esposa, por uma amiga desta e por outros participantes da narrativa. No capítulo 12, por exemplo, é a sua irmã quem começa o relato, até que o filho preto assume-o, definitivamente: "este capítulo, que devia ser eu a escrever, a minha irmã roubou-mo" (p. 236). Contudo, também o pai carrega a voz da sua esposa, do médico que a trata (ou tenta tratar, porque a mulher está com um câncer inoperável), do seu pai, do seu irmão e também a de uma prostituta do tempo da juventude (no capítulo 15). A esposa e a filha ganham seus próprios capítulos, respectivamente, no 19 e no 21 .

Essas vozes que se atravessam dentro da consciência de uma personagem que também é narrador autodiegético cabem na categorização proposta por Brian Ri- 
chardson: permeable narrator. Richardson assim define essa categoria: "uncanny and inexplicable intrusion of the voice of another within the narrator's consciousness. I call such a figure a 'permeable narrator" (RICHARDSON, 2006, p. 95). Ou seja, a transgressão de um narrador criado na primeira pessoa verbal ao invadir a consciência de outras personagens da história tal e qual uma voz onisciente. Isso pode ser percebido quando o filho preto recupera uma cena em que ele e o pai levam a mãe para o Hospital. A mãe sofre de câncer, mas o diagnóstico é supostamente escondido dela: não câncer, mas pedras enormes no rim. O filho observa a mãe, que por sua vez evita olhar para o marido e "se sentir culpada de deixar de tomar conta dele, tão indefesos os homens, tão frágeis” (p. 121). O adensamento do processo narrativo dá-se quando a personagem do filho, que supostamente consegue invadir a consciência da mãe e relatar o que ela pensa naquele exato momento, tem o seu discurso contaminado pelo da mãe: "tão indefesos os homens, tão frágeis, tão incapazes de sobreviver sem a gente [...] e o que será da tua vida depois de mim coitadinho, a barba mal feita, sapatos por engraxar, um botão a menos na camisa" (p. 121). A interferência da mãe em antecipar sua própria morte, comiserada com a dependência do marido, é uma pista de que, em verdade, já sabe do diagnóstico que dela tentam esconder, fato que se confirma quando a mãe ganha seu próprio capítulo.

Richardson retoma Genette e afirma que muitos autores contemporâneos recusam uma escolha entre as duas possibilidades de construção narrativa sublinhadas pelo crítico francês: "either to have the story told by one of its characters, or to have it told by a narrator outside the story. It is, however, precisely this choice that is rejected by so many contemporary authors" (RICHARDSON, 206, p. 5-6). E é esta a recusa que os narradores antunianos assumem, já que estão num dentrofora de suas próprias consciências, a todo momento mergulhando no pensamento dos outros.

Os autores contemporâneos ultrapassam fronteiras previamente definidas e, junto com seus enredos, compõem mecanismos narrativos, que igualmente devem ser decifrados pelo leitor. Aliás, Brian Richardson sublinha a necessidade de o leitor perceber o quão desafiador é a leitura dessas obras: "If a narrative is, as commonly averred, someone relating a set of events to someone else, then this entire way of looking at narrative has to be reconsidered in the light of the numerous ways innovative authors problematize each term of this formula" (RICHARDSON, 20006, p. 5). Paul Ricoeur, no terceiro volume de Tempo e narrativa, em capítulo que relê a Retórica da ficção de Wayne Booth, diz: "Não se pode contestar que a literatura moderna seja perigosa. A única resposta digna da crítica que ela provoca, e da qual Wayne Booth é um dos representantes mais estimáveis, é a de que essa literatura venenosa requer um novo tipo de leitor: um leitor que responde" (RICOEUR, 1997, p. 282).

O veneno de Lobo Antunes na concepção de sua obra é romper o que tradicionalmente conhecemos por um narrador de primeira pessoa, porque como avisa Richardson, este é um autor que rejeita um modelo mimético. O crítico assinala 
que, em tese, um narrador em primeira pessoa não pode entrar na mente de outras personagens, mas em seguida argumenta: "these rules, however, have always been more frail and arbitrary than narrative theorists have usually wanted to acknowledge"(RICHARDSON, 2006, p. 7).

Outra interessante marca observável na narrativa, e também ela anotada por Brian Richardson, é a alteração da pessoa verbal sem maiores licenças, como no capítulo 5, em que o homem que lutou em Angola sobrepõe dois eventos de tensão a partir do atraso na chegada de duas personagens à aldeia: o irmão, anos atrás, que nunca chegava porque morto num acidente de carro (e naquele tempo era o pai e não ele quem estava preocupado), e no presente, o atraso do filho preto para o ritual da morte do porco. Esta justaposição temporal acarreta o embaralhamento da voz que narra: o homem, em primeira pessoa, recorda o irmão - "e o meu irmão um gesto vago a provar a comida na panela [...] do meu tamanho mas mais bonito, mais magro, as unhas dele perfeitas" (p. 10o) - mas em seguida dirige-se a ele, numa segunda pessoa: "não para ofendê-lo a ele, para ofender-te a ti que me protegias sempre, me davas dinheiro, às vezes acariciavas-me a bochecha e eu a limpar com a manga recuando" (p. 101).

O improvável é potencializado quando a voz do irmão morto emerge na narrativa do soldado:

$$
\begin{aligned}
& \text { nós dois no café, tu e eu no café, tu } \\
& \text { - Agora que estou morto já podemos falar } \\
& \text { E ao longo destes anos temos falado não achas (p. 101). }
\end{aligned}
$$

Genette (2017, p. 314) chamou de metalepse essa quebra dos limites narrativos, a passagem de um nível a outro. Uma personagem morta no mundo diegético que, de repente, quer dialogar com outra, ou ainda uma segunda personagem morta, desta vez o pai do soldado, que, de acordo com o narrador, faleceu há quase vinte anos, e ainda lhe faz perguntas. É, aliás, esta outra cena emblemática, quando o pai rejuvenescido surge em África a comentar eventos que nunca viveu. Como se a personagem com a qual o soldado sempre teve uma relação difícil, e de quem teria herdado uma personalidade moralista e conservadora - discorreremos sobre isso mais tarde -, estivesse tão presente em suas censuras que mesmo no passado rememorado a sua influência o fizesse materializar-se lá. Observemos que o narrador-personagem parece estar a preparar o corpo do pai num caixão, quando vêm as interferências:

enquanto eu compunha o meu pai cerrando-lhe os olhos com os polegares e encaixando-lhe a dentadura postiça no queixo, ele logo mais novo, com menos rugas na cara, a perguntar-me

- Aquele pequenino ao pé dos unimogues a mandar ires-te foder é que é o major (p. 103) 
A cena surreal, simbolicamente percebida como uma impossibilidade de definitivamente matar e enterrar este pai, tem, em seguida, o comentário do psicólogo do hospital, a fazer as vezes de um leitor crítico: "Isto é para antigos combatentes quem lhe deu licença de meter aqui o seu pai?” (p. 103).

Há uma série de outras artimanhas narrativas que chamam a atenção em Até que as pedras se tornem mais leves que a água, contudo, esses exemplos até aqui trazidos conseguem dar conta do todo de sua construção. Porque me interessa essa discussão apenas para percebermos que a construção narrativa não é, evidentemente, gratuita. Essa ligação entre contrários, uma vez que um acaba interferindo e engolindo a voz do outro, em especial essa espécie de canibalismo entre a voz dos dois protagonistas, absolutamente perceptível no último capítulo, quando ora o pai, ora o filho negro narra, a ponto de em diversos momentos não termos certeza de quem é quem, pois ambos poderiam ter pensado aquilo, é importante para analisarmos um aspecto que considero fundamental nessa obra, que é uma recusa absoluta ao patrimônio oferecido pelo pai ao filho, o que pretendo debater na próxima seção.

\section{Da negação do patrimônio ao grito do subalterno}

Do porco, se aproveita tudo. Menos o berro.

Charles Kiefer

Tomo emprestada, aqui, a definição de patrimônio desenvolvida por Margarida Calafate Ribeiro e Walter Rossa, na obra Patrimônios de influência portuguesa: modos de olhar. No texto, os autores ressaltam que o uso do plural do título relacionase a uma multiplicidade de percepções a partir da influência portuguesa - espécie de operador comum - a diferentes setores interculturais. Para os autores (2015, p.22), há duas pedras angulares neste sentido - língua e território - sobre as quais um modo de olhar interdisciplinar e pós-colonial deve ser lançado.

Ribeiro e Rossa destacam que o território nunca é terra de ninguém, mas património de alguém (RossA; Ribeiro, 2015, p. 23), e essa relação de pertença (ou não pertença) em relação a ele é parte integrante das questões identitárias: "desterrar, deslocar, expatriar são, entre outros, termos que ilustram de forma dramática a relevância da relação entre território e identidade" (RossA; RibEIRo, 2015, p. 23). Tem a língua papel complementar, porque assim como a definição dos territórios, sempre móveis, também ela, quando lançada numa viagem planetária, e em contato com o novo - novos lugares, povos, outras línguas, ajusta-se, modula-se, construindo aquilo que João de Barros chamava de nosso edifício. Ao mesmo tempo, é a língua portuguesa um instrumento político de evangelização e de poder, e a necessidade de unicidade em espaços multilíngues, como nos casos das colônias, provoca muitas fraturas. Eduardo Lourenço igualmente relaciona patrimônio à iden- 
tidade, e inclui no primeiro "os símbolos, os sinais, os modos, o discurso que nos identifica” (LOURENÇO, 2015, p. 149).

Penso que a reflexão de patrimônio tem relação direta com a percepção de distintas perspectivas a partir de um passado forçosamente comum, constituído em meio à violência, uma vez que, já nos avisa Boaventura de Sousa Santos, todo o colonialismo é mau, "e só uma ideologia histórica dominada pela ideia do progresso permite justificá-lo nos termos dúbios de que os fins justificam os meios" (SANTos, 2014, p. 248). Essa também parece ser a ideia de Renata Araujo, no texto "Influência, origem, matriz", em que afirma que, para pensar em patrimônio, é necessário pensar em partilhas. A teórica chama atenção para algo muito mais profundo do que um mero jogo de palavras: a diferença entre "a partilha de um suposto passado comum e a partilha comum dos diferentes passados" (ArAUjo, 2015, p. 61). Porque podemos pensar que, acrescida à violência já existente no processo, há uma outra violência, mais simbólica, na tentativa de comungar um passado que não foi, evidentemente, comum (porque não foi percebido da mesma forma) para colonizador e para colonizado.

Roberto Vecchi, em "Identidade, herança, pertença", debate algo similar. O teórico sublinha que, num contexto familiar, o patrimônio é um conjunto de bens materiais deixado aos seus herdeiros. Contudo, o crítico avança sua argumentação para a esfera pública, atravessada pela hierarquia, pelo poder. Um poder recuperado junto a Derrida, sempre relacionado a um fantasma, porque patrimônio tem relação com propriedade, com posse, com poder, "no sentido que pode ser um domínio mas também uma atribuição, efetiva ou simbólica - sobre um objeto" (VECCHI, 2015, p. 74), mas também tem a ver com rastro, com ausência, com "perdas, resistências, sobrevivências, aspectos que não remetem para qualquer narração deslumbrante e eloquente" (VECCHI, 2015, p. 77).

Cabe agora, portanto, outra vez nos aproximarmos da narrativa antuniana. $\mathrm{O}$ ato simbólico do pai que destrói a aldeia e dizima todos, menos esta criança, traz uma série de violências, incluindo aí uma menos óbvia, que é a da decisão pelo futuro do menino, arrancado de sua cultura e incorporado na cultura alheia, do conquistador. Ao mesmo tempo em que o filho reproduz o discurso do pai, por toda a narrativa, numa aparente aceitação deste patrimônio de influência portuguesa a ele imposto, ele também prepara-se para matá-lo. A morte do pai é a evidente negação deste patrimônio. De acordo com a personagem paterna, o miúdo sempre olhou para o pai com um olhar ausente, que dizia mais do que parecia. Quer dizer, o interessante nas personagens antunianas desta obra é que quase todas as palavras ditas são projeções das próprias personagens; ficam no campo das hipotéticas falas a partir de uma percepção que essas personagens têm de si mesmas e do modo como o outro as enxerga. No caso específico, o pai percebe qualquer coisa condenatória no filho: "O miúdo que até hoje, já homem, não cessou de fitarme, a sentir não sei o quê, a pensar não sei em quê, sem me tocar nem abraçar nunca que os pretos não tocam nem abraçam" (p. 206). A inexistência do afeto real 
também camufla a culpa deste pai, sentimento chave de toda a narrativa. Mesmo aquilo que nem dito é, condena-o: "O silêncio dele a acusar-me" (p. 326).

Já na perspectiva do filho, o leitor percebe que há, sim, qualquer coisa mal engendrada no complexo edifício construído junto a seu pai. Não poderia ser diferente, e este hoje adulto rememora, atormentado, lembranças lancinantes: "não era capaz de proteger a mulher que me introduzia na boca o seio vazio nem o homem que nunca olhou para mim e morava com ela" (p. 191), essa mesma mulher "de mãos cortadas que se inclinava devagarinho para mim sem me tocar, quase sem me tocar, tocando-me, falando comigo numa língua que eu não entendia" (p. 239), num difuso exercício de memória e de negação: a língua nativa negada e então incompreensível aos olhos de quem hoje, aportuguesado, rememora. A mãe biológica não mãe, mas "uma pessoa que me estendia o peito" (p. 164), uma vez que a mãe verdadeira é aquela de hoje. Renuncia, portanto, às origens: terra, língua, família. Entretanto, o seu raciocínio é a todo instante desfeito, porque sempre contraditório, já que "o meu pai não é meu pai nem a minha mãe minha mãe embora ache que são, ou seja acho que são e não são" (p. 41).

A absurda dificuldade em verdadeiramente viver junto ao patrimônio português herdado por esse homem que se desmorona, que grita à noite com assombros de África, torna a sua tarefa de aceitação mais complicada. Ainda que a memória seja pouco confiável, exemplificada em diversas cenas de gradação nas incertezas daquilo que conta: "Talvez tenha inventado, talvez tenha sonhado, talvez outro miúdo, não eu, a abraçar a mulher, de certeza que outro miúdo a abraçar a mulher" (p. 41).

Este passado remoído, retorcido, misturado a um presente infeliz contribui para uma percepção rasurada de si próprio: "Esclareçam-me em que me tornei e quem sou eu hoje em dia, esclareçam-me por favor" (p. 43).

No texto "Subalternidades no(s) Atlântico(s) Sul", no qual resgata os subaltern studies, Roberto Vecchi traz a imagem dos monumentos como símbolos de um patrimônio, não sem esquecer a violência que percorre o processo: "Como pensar a monumentalidade fora de categorias apaziguadoras, mas de facto violentas, como identidade, tradição, herança e pertença" (Vecchi, 2016, p. 77). Esses monumentos são derrubados pelo filho preto, um a um. Sua memória e suas convicções são por demais frágeis para deixá-los em pé. A personagem está inserida num contexto que lhe aborrece, num casamento infeliz repleto de constrangimentos. Tudo the desagrada. Vive num país que não o aceita. Sofre o racismo todos os dias. Vivencia a disparidade salarial e a justifica pela cor de sua pele: "no emprego me pagam menos que aos outros, sou preto" (p. 306).

O texto de Lobo Antunes mergulha neste tenebroso mar das memórias nem sempre vividas, mas também forjadas. E falo de memórias forjadas na perspectiva da personagem removida de sua terra, de seus laços, de suas raízes; uma personagem que chama a atenção por uma capacidade de detalhismo de uma guerra que 
não foi sua, mas que condicionou seu futuro. O filho preto do homem soldado reproduz uma memória que não é a sua, mas a de seu pai, na perspectiva do colonizador. Mais grave, portanto, do que as lacunas daquilo que (não) lembra, é todo aquele material que lhe é imposto.

Junto a isso, a personagem coleciona xingamentos e impropérios, alguns recolhidos daqueles que com ele têm convivido ou conviveram, o avô, a avó e principalmente a esposa. "Tresanda a catinga este" (p. 338), dizia a avó, que o tratava pela expressão pejorativa escarumba. "Vocês parecem-se todos uns com os outros" (p. 124), diz a mulher do filho preto, a reproduzir o estereótipo de que os negros são sempre parecidos. Ao preconceito de raça, ela equipara o de classe, uma vez que, como afirma Vecchi, existe uma "substancial sinonímia entre raça e classe com base na qual negro e pobre são, na realidade, condições coincidentes" (VecchI, 2016, p. 188).

A vida de merda que a esposa levava era por culpa do marido: "um carro de merda, um preto de merda, uma vida de merda" (p. 125). Todavia, ele contrapõe: "Mas o dinheiro que o preto ganha, mesmo pouco, dá jeito e além disso obedece, contenta-se, não pretende mandar, não se atreve a zangar-se" (p. 304). Sublinha suas características de passividade, daquele que aparentemente aceita uma nova vida, mesmo que não a tenha pedido, reforçando, ironicamente, o lugar-comum assombrado dos 'selvagens' quando ganham badulaques: "sempre submisso, humilde, enfeitado com pulseiras e relógios que brilham” (p. 304).

Mesmo as personagens que apenas orbitam a sua vida gritam preconceitos a reforçarem seu sentimento de inadequação - a empregada do refeitório da escola a dizer: "É melhor ferver os talheres depois sei lá as doenças que ele tem" (p. 194); ou o sargento: "não são pessoas meu alferes, convença-se do que lhe digo nunca foram pessoas" (p. 210). Ou a vizinha do segundo andar para uma amiga: "Não sentes o cheiro a macaco?" (p. 227).

Entretanto, o que chama a atenção é que, muitas vezes, as ofensas racistas proferidas não saem da boca dos outros. Observemos a seguinte cena:

\author{
Sua Excelência a mirar-me com desgosto \\ - Escarumba \\ e eu a aceitar o \\ - Escarumba \\ eu humilde, eu subsidiário, eu obediente (p. 117).
}

Fica na passagem bastante claro que a esposa, a quem ironicamente a personagem denomina de Sua Excelência, olha para ele com algum tipo de desprezo, ou essa é a percepção que ele possui do momento. Não há marcação na narrativa de que teria ela dito a ofensa. O filho preto, portanto, reproduz um sem número de preconceitos deste senso comum dos discursos racistas, num terrível repertório: "sou um marido preto a cheirar a preto" (p. 117); "e para além de cheirar a preto 
aquele nariz esborrachado, aquela boca grossa, aquele cabelo impossível de pentear a não ser com um prego ou caco de vidro" (p. 117). São frequentes as comparações com macacos: "eu um chipanzé encontrado num quimbo" (p. 123), numa recorrência da primitivização do negro: "porque os pretos são estúpidos não é, não entendem não é, devíamos atirar-lhes uns amendoins e pronto, uma banana não é" (p. 48); "aliás a gente os pretos, tão próximos dos macacos, nem sonhamos o que é isso, matamos galos à dentada, comemos vísceras cruas, não tapamos as vergonhas" (p. 111); "eu um saguim bom para se passear nas árvores" (p. 125).

O mais perturbador na narrativa antuniana é a inexistência de ao menos uma voz que contradiga o rosário de ofensas contra o africano, contra o negro. Todas as personagens, inclusivamente o negro, contribuem para a construção de um discurso de racismo, do início ao fim das quase 500 páginas. E é a autodepreciação da personagem filho preto que mais choca. Já observamos, igualmente, seu discurso de subserviência, na passagem que diz "eu humilde, eu subsidiário, eu obediente". É o discurso do silenciado, do subalterno.

Ainda em "Subalternidades no(s) Atlântico(s) Sul", Vecchi ocupa-se de uma discussão cara ao século XXI: a questão da voz, ou do protagonismo, das minorias, especificamente o negro. Ao examinar o espaço ocupado, na literatura e não só, do escravo, do escravo alforriado e de seus descendentes, o crítico resgata os estudos de Gayatri Spivak: Pode o subalterno falar? Mesmo para chegar à resposta que sim, contrariando a autora indiana, pode o subalterno falar, "o murmúrio vivo e palpitante das subalternidades silenciadas do(s) Atlântico(s) Sul ainda pode ser ouvido e interpretado criticamente. E assim, pela sua Voz feita de vozes, as suas contrahistórias não-hegemónicas podem começar a ser contadas” (Vecchi, 2016, p. 201), mesmo para atingir esse pensamento final, o texto passeia por muitos elementos de opressão que levariam/levaram/levam o negro ao silenciamento. Ou, como mesmo afirma Spivak no texto original, o caminho do debate passa por "uma rota necessariamente tortuosa" (SPIVAK, 2010, p. 20). ${ }^{2}$

É aqui que pretendo aproximar este debate da voz do negro com a arquitetura narrativa de Até que as pedras se tornem mais leves que a água. O filho preto arrancado de África tem seu discurso contaminado pela voz paterna, e essa voz paterna engloba o discurso de uma nação imperialista, carregando séculos de um olhar colonizador. Filho e pai, africano e europeu, dividem seu discurso, mas a visão do pai domina a narrativa. Uma história particular de conservadorismo, homofobia, machismo e racismo, que já se mostra evidente na voz recuperada do avô e na do pai do homem que trouxe um menino negro de África. Três gerações marcadamente fortes e presentes de maneira sufocante na criação deste filho preto, que reproduz a fala de seus "antepassados". Não os seus antepassados verdadeiros, africanos di-

\footnotetext{
2 Não pretendo, aqui, também eu silenciar o discurso de Spivak em favor do de Vecchi - homem, branco e europeu. Ao contrário, utilizo a contextualização de Vecchi dos estudos de Spivak à realidade das ex-colônias portuguesas, tema que me é central para este artigo.
} 
zimados na guerra colonial, mas os seus antepassados postiços. Também a construção de família deste sujeito é uma violência.

É possível relacionar a execução narrativa na obra de Lobo Antunes com a forte imagem, recuperada de Spivak por Vecchi, de ventriloquismo. Primeiramente, porque a idade que tinha o filho preto, quando arrancado de África, não lhe permitiu a construção de lembranças fidedignas, como já levantei aqui neste estudo, e sobre o qual trago outros exemplos: "disso recordo-me, julgo recordar-me, recordome mas não sei se invento a memória, episódios tão difusos, tão vagos” (p. 124) e "tudo se me confunde na memória" (p. 246).

Ainda que o estudo da memória não seja o meu objetivo nesta discussão, cabe lembrar as ideias de Maurice Halbwachs, quando este afirma que recorremos aos outros para reforçar ou enfraquecer o que sabemos sobre determinado evento, porque a "nossa impressão pode se basear não apenas na nossa lembrança, mas também na de outros" (HALBWACHs, 2003, p. 29). Isso porque a memória é coletiva, é construída a partir daquilo que nós recordamos e também daquilo que os outros recordam de nós (e por nós). É este mecanismo de (re)captura de cenas passadas bastante evidente em Até que as pedras se tornem mais leves que a água, haja vista a forma como o filho preto tece seu discurso sobre a África. Por isso, acredito que a imagem do ventríloquo é profícua na relação dessas duas personagens: pai e filho. O pai com o filho no colo: o negro a fingir que fala o que na verdade é o pai branco que diz. Como se o filho preto tivesse incorporado a voz do outro, e negado, por consequência, a sua própria, numa representação de poder e hierarquia. Representação em sentido político e estético para Vecchi, já que o subalterno fala em nome de, e os imbricamentos entre esses dois polos aprofunda o silenciamento do excluído, tornando-se ele uma representação de seus autores em transparência (2016, p. 192). O filho preto fala em nome do pai, ou pior, o pai fala pelo filho. Até o momento em que o filho decide matá-lo.

\section{Encaminhamentos finais: matar o que já morreu em África}

\footnotetext{
O futuro reduz-se às proporções angustiantes de um túnel onde se penetra mugindo a dor antiga que se não consegue sarar, antiga como a morte que dentro de nós cresce.
}

Lobo Antunes

A concepção narrativa transgressora, em que narradores em primeira pessoa conseguem aproximar-se da consciência de outras personagens e, mais ainda, capturam suas vozes, ou por ela são dominados, revela, no texto em análise, uma característica que me parece fundamental: essa contaminação entre as vozes acaba por produzir (ou reproduzir) um discurso dominante, o discurso do colonizador. São raras as passagens em que a personagem do filho preto traz algum tipo de voz 
crítica. Contraditoriamente, porém, desde o início da narrativa já sabe o leitor que o filho matará o pai, e esse fato, por si só, reduz a pretensa apatia do negro e sua relação de subserviência frente ao pai.

O pai que pensa no filho preto como obstáculo, como um arrependimento. Que pensa no filho e deduz a impressão da nora, que também não deixa de ser a sua

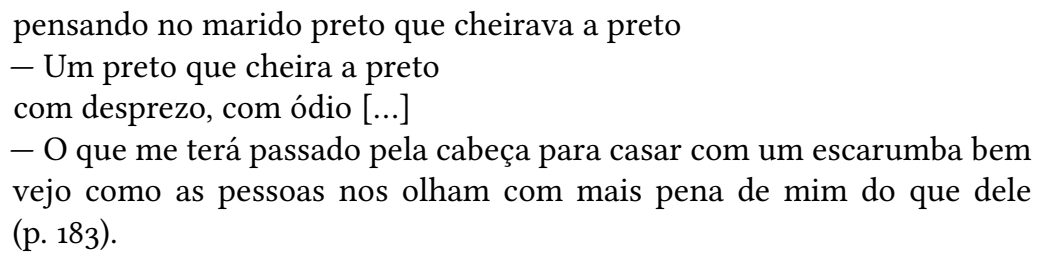

O pai que tem ódio dos pretos, como na cena por ele resgatada da inversão de espaços ocupados: um motorista branco a abrir as portas de um automóvel ocupado por negros bem-vestidos. A cena é longa, mas considero oportuna:

\begin{abstract}
um motorista branco abria com respeito a porta traseira de um automóvel caro, com matrícula diplomática, de que saíam, a rirem-se, um par de pretos muito mais bem vestidos do que eu, sem me estenderem as latas ferrugentas pedindo comida, desprezando-me isto é não me olhando sequer, nunca dei por calças tão engomadas, nunca vi sapatos tão engraxados, nunca senti tanto cheiro de perfume francês, nunca desejei tanto estar com uma arma como nessa altura e varrê-los, olhar os corpos deles no chão, pulando a cada bala, nunca me apeteceu tanto pedir a faca a um cabo e cortar-lhes as orelhas, as mãos (p. 147).
\end{abstract}

Tal cena recupera uma série de preconceitos na percepção humilhada do pai, a sentir-se pior que o par de pretos, a ter instintos de ódio contra a ostentação, a não ter o que eles têm e se considerar mais merecedor apenas por ser branco.

No outro lado da corda, o filho. O preto que não percebe amor do pai adotivo por ele: "o meu pai que não gostava de mim, me usava na esperança de que gostasse dele" (p. 192). Ele uma qualquer coisa utilitária a servir de expiação da culpa do pai. Ele, uma orelha arrancada, um troféu - "Não serei eu todo as orelhas que ele cortou não serei o seu troféu?" (p. 45).

Para Roberto Vecchi, a questão pós-colonial traz uma indecidibilidade, na consciência de uma fratura irreversível no sentimento de pertença. Diz Vecchi, e tanto nos diz o crítico sobre a narrativa aqui estudada:

O sentimento de propriedade (colonial) do passado abre espaço a uma outra relação de posse, também insuficiente, que se esvazia no gesto do velho português que segura nas mãos uma pedra da estátua antes de jogála no chão. Pedra que se estilhaça e se torna poeira: ruína que se destrói 
e não deixa margem a nenhum sentido possível porque é indecidível, no vazio, tanto na pertença (de quem era, de quem é) como na disputa da memória (VeCCHI, 2015, p. 75).

O velho português, o pai, o soldado que foi à África, que incorpora o discurso de seu pai, e do pai do seu pai, é obviamente a cristalização de todo um passado opressor. Mas em mãos tem esse soldado português matéria esfacelada, desconstruída, também ele num processo de rememoração e dor, e de quase alívio na certeza de uma morte próxima. Segura nas mãos o patrimônio, mas "um patrimônio que retém fisicamente o que está em risco de perder-se para sempre, nunca será base possível de alguma fundação futura. Como o murmúrio, o grito ou o sofrimento" (VeCCHI, 2015, p. 78).

Como o grito do porco, morte anunciada que se faz presente do início ao fim da narrativa. Curiosamente, a ação terá como protagonista aquele que se mostra fraco e calado, obediente a uma esposa Sua Excelência que só sabe fazer exigências, aquele fraturado, sem identidade:

só os brancos podem queimar, matar, cortar orelhas e à gente cabe-nos o destino de sermos queimados, mortos, amputados e portanto para que outra identidade, outra terra, outros pais, se não saí de África, continuo em África, morrerei em África erguendo os cotos para os brancos (p. 79).

O filho preto recusa o destino, ou o patrimônio: matará e morrerá no dia de matar porcos, aqui nesta aldeia portuguesa perdida no mapa, lá na África onde já morreu. Porque se a África é o lugar em que "tudo come tudo" (p. 181), o filho matará o pai e a cena não poderia ser mais carregada de simbolismo nesta anunciação do fim, em que tudo será devorado

degolem-me o pescoço sobre o pescoço dele, encham as minhas tripas conforme enchem as suas, cozinhem-nos, comam-nos, ofereçam as nossas patas a um vizinho, os nossos braços a outro [...] larguem o que sobrar aqui e vão-se embora depressa esquecidos da gente (p. 302).

Esqueçam-se desta história. Apaguem o que já foi escrito, porque, avisa Vecchi, "o subalterno se define ontologicamente por um vazio de representação, pelo seu silêncio entre as vozes da história" (Vecchi, 2016, p. 191). Vazio que será preenchido pelo movimento da faca, a mesma que matará o porco. Pai e porco fundidos:

enquanto alguém esquartejava o porco por nós, o que ele gritou senhores, a quantidade de vezes que chamou

- Rapaz

com a mão no meu ombro, que chamou

- Rapaz 


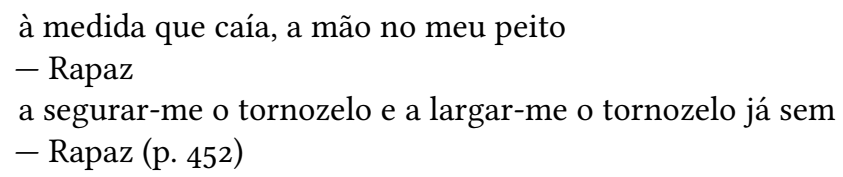

Personagens do passado a comentarem o agora. Como o capitão que lá da África fala: "o miúdo preto matou o alferes com a faca do porco" (p. 452). Na confissão de que mata a África, de que mata o passado: "gostava dele, não queria, não foi o meu pai que eu matei, foram os tiros e a guerra, o gasóleo, o fogo" (p. 453).

E no nascimento de uma quase ternura, um quase amor: "- Estou bem. Apesar do meu pai no chão do cimento e eu de joelhos ao pé dele, quase a abraçá-lo, até os guardas chegarem" (p. 454).

E talvez o silêncio na espera, talvez o choro da mãe que também assiste, com certeza o pedido da irmã, a fazer eco ao do irmão: "mal acabem a última linha deste livro cheguem-lhe um fósforo para que nada sobeje da gente, do que aqui ficou escrito e nos esqueçam" (p. 227).

Porque é difícil lembrar.

Queimem, apaguem, esqueçam. O resto é aquilo "que permanece na areia da memória quando as águas do passado recuam” (p. 120).

Porque é difícil esquecer.

\section{Referências}

Antunes, António Lobo. Até que as pedras se tornem mais leves que a água. Lisboa: D. Quixote, 2017.

Antunes, António Lobo. Até que as pedras se tornem mais leves que a água (crónica). Visão, Lisboa, 18 ago. 2016. On-line. Disponível em https://goo.gl/9cGqYf. Acesso em: 14 mar. 2018.

Antunes, António Lobo. Os cus de fudas. 21. ed. Lisboa: D. Quixote, 2001.

Araujo, Renata. Influência, origem, matriz. In: Rossa, Walter; Ribeiro, Margarida Calafate (Org). Patrimônios de influência portuguesa: modos de olhar. Niterói: EdUFF, 2015.

Genette, Gérard. Figuras III. São Paulo: Liberdade, 2017.

Halbwachs, Maurice. A memória coletiva. São Paulo: Centauro, 2003.

KIEfER, Charles. Dia de matar porco. Porto Alegre: Dublinense, 2014.

Lourenço, Eduardo. Entrevista concedida a Margarida Calafate Ribeiro, Walter Rossa e Roberto Vecchi. Março de 2015. In: Rossa, Walter; Ribeiro, Margarida Ca- 
lafate (Org). Patrimônios de influência portuguesa: modos de olhar. Niterói: EdUFF, 2015. p. 149-170.

RICHARDSON, Brian. Unnatural voices: extreme narration in modern and contemporary fiction. Columbus: Ohio State University Press, 2006.

Ricoeur, Paul. Mundo do texto e mundo do leitor. In: Ricoeur, Paul. Tempo e Narrativa. Campinas: Papirus, 1997. v. III.

Rossa, Walter; Ribeiro, Margarida Calafate (Org). Patrimônios de influência portuguesa: modos de olhar. Niterói: EdUFF, 2015.

Santos, Boaventura de Sousa. A cor do tempo quando foge. São Paulo: Cortez, 2014.

SpIVAK, Gayatri C. Pode o subalterno falar? Belo Horizonte: UFMG, 2010.

Vecchi, Roberto. Identidade, herança, pertença. In: RossA, Walter; Ribeiro, Margarida Calafate (Org). Patrimônios de influência portuguesa: modos de olhar. Niterói: EdUFF, 2015.

Vecchi, Roberto. Subalternidades no(s) Atlântico(s) Sul. In: Ribeiro, António; RiBEIRO, Margarida Calafate. Geometrias da memória: configurações pós-coloniais. Porto: Afrontamentos, 2016.

Recebido em 24 de junho de 2018.

Aprovado em 19 de novembro de 2018.

\section{Resumo/Abstract/Resumen}

Em nome do pai: ventriloquismo e subalternidade em Até que as pedras se tornem mais leves que a água, de António Lobo Antunes.

\section{Paulo Ricardo Kralik Angelini}

A guerra é um tema recorrente na obra de António Lobo Antunes, especialmente em boa parte de seus primeiros romances. Com Até que as pedras se tornem mais leves que a água, seu mais recente trabalho, o autor revisita a África ao trazer dois sobreviventes (ou serão duas vítimas?) de uma guerra. O enevoado da narrativa recupera, predominantemente a partir de dois pontos de vista, mais do que o combate em Angola, os conflitos de um soldado e um menino arrancado de África. Pai e filho compõem uma simbiose dissonante, porque carregada de vínculos opostamente construídos. A estrutura narrativa obedece a um jogo de poder, e entre vozes, incorporações de vozes outras e amordaçamentos, sintetiza um mundo diegético no qual esse filho que sempre falou como o pai pretende, por fim, negar 
seu patrimônio e silenciá-lo. Para a articulação teórica, utilizo autores como Gérard Genette, Brian Richardson, Gayatri Spivak, Roberto Vecchi, Margarida Calafate Ribeiro, entre outros.

Palavras-chave: literatura portuguesa, António Lobo Antunes, narrador, patrimônio.

In the name of the father: ventriloquism and subalternity in Até que as pedras se tornem mais leves que a água, by António Lobo Antunes.

\section{Paulo Ricardo Kralik Angelini}

The war is a recurring theme in the work of António Lobo Antunes, especially in much of his early novels. With Até que as pedras se tornem mais leves que a água, his latest work, the author revisits Africa with the story of two war survivors (or two victims?). The misty narrative addresses, predominantly from two points of view, more than the war in Angola, the conflicts of a soldier and a boy plucked from Africa. Father and son construct a dissonant symbiosis which is loaded with opposite-built bonds. The narrative structure obeys a game of power and between voices, incorporations of other voices and the gagging of others, synthesizes a diegetic world in which this son, who has always echoed his father, ultimately intends to deny his patrimony and silence him. For the theoretical assumption, I use authors such as Gérard Genette, Brian Richardson, Gayatri Spivak, Roberto Vecchi, Margarida Calafate Ribeiro, among others.

Keywords: portuguese literature, António Lobo Antunes, narrator, patrimony.

En el nombre del padre: subalternidad y ventriloquía en Até que as pedras se tornem mais leves que a água, de António Lobo Antunes.

\section{Paulo Ricardo Kralik Angelini}

La guerra es un tema recurrente en la obra de António Lobo Antunes, especialmente en muchas de sus primeras novelas. Con Até que as pedras se tornem mais leves que a água, su último trabajo, el autor revisita África trayendo dos supervivientes (¿o serán dos víctimas?) de una guerra. La narrativa brumosa recupera, predominantemente desde dos puntos de vista, más que la lucha en Angola, los conflictos de un soldado y un niño arrancado de África. El padre y el hijo conforman una simbiosis disonante, cargada con lazos de construcción opuesta. La estructura narrativa obedece a un juego de poder y, entre voces, incorporaciones de otras voces y amordazamientos, sintetiza un mundo diegético en el que este hijo, que siempre ha hablado como el padre, tiene la intención de negar, en última instancia, su patrimonio y silenciarlo. Para la articulación teórica, utilizo autores como Gé- 
rard Genette, Brian Richardson, Gayatri Spivak, Roberto Vecchi y Margarida Calafate Ribeiro, entre otros.

Palabras clave: literatura portuguesa, António Lobo Antunes, narrador, patrimonio. 